\title{
Extensive, neglected basal cell carcinoma of the half of the face-surgical treatment and reconstruction with an anterolateral microvascular thigh flap
}

\author{
Katarzyna Malec ${ }^{1}$, Paweł Brzewski ${ }^{2}$, Paweł Cenda ${ }^{1}$, Krzysztof Kuchta ${ }^{1}$, Mateusz Gasiński ${ }^{1}$, Anna Wojas-Pelc ${ }^{2}$, \\ Maciej Modrzejewski ${ }^{1}$
}

${ }^{1}$ Department of Otolaryngology, $5^{\text {th }}$ Military Hospital with Polyclinic, Krakow, Poland ${ }^{2}$ Department of Dermatology, Collegium Medicum, Jagiellonian University, Krakow, Poland

Adv Dermatol Allergol 2016; XXXIII (3): 235-238

DOI: 10.5114/ada.2016.60618

Basal cell carcinoma (BCC) is the most common malignancy in humans [1, 2]. According to the Skin Cancer Foundation, estimated 2.8 million cases are diagnosed annually in the US. Non-melanoma skin cancers (NMSC), the most common neoplasms in Europe, the USA and Australia, despite their low mortality, pose a serious therapeutic, social and economic problem. Worldwide incidence is increasing by about $10 \%$ per annum, so the prevalence of basal cell tumor in the near future will equal that of all other cancers together [3]. Basal cell carcinoma occurs in 85-90\% of cases on the head, often on the face above the line connecting the mouth corner with the ear lobe [4]. They are less often found in the lower part of the face and on the scalp. In 10-15\% of cases, BCC is found on the neck, trunk and limbs. Location of the basal cell carcinoma is closely related to the exposure to ultraviolet radiation $[5,6]$. Although rarely metastatic, it has potential of tremendous, in some locations, lifethreating, regional destruction and disfigurement [7].

Diseases on the surface of the skin are usually visible and tend to be easily noticed both for health-care professionals and for patients themselves. However, cases of neglected, extensive skin neoplasms are still a fairly common phenomenon in the $21^{\text {st }}$ century.

There are several different methods of treatment of BCC tumors: surgical (simple excision, Mosh' micrographic surgery), destructive (cryosurgery, curettage and cautery) and non-surgical (photodynamic therapy, radiotherapy, topical-5-fluorouracil, imiquimod) [8, 9].

An advantage of surgical proceeding is the possibility of meticulous histological examination of the tumor type and margins of excision to establish clearance.
Early treatment produces cure rates of almost 100\% (the suggested overall 5-year cure rates for primary and recurrent BCC are $99 \%$ and $94.4 \%$, respectively) [10, 11]. In order to decide on the adequate treatment option, several factors should be taken into consideration: biological, histopathological and clinical features of the neoplasm as well as the patient condition. Exact determination of the skin cancer margins is of particular importance in case of lesions developing in areas where the reoperation of a recurring neoplasm would not be possible. When excision is incomplete, the recurrence rate is approximately $30 \%$ [12].

Basal cell tumors are easily treated in their early stages. The larger the tumor has grown, however, the more extensive the treatment is needed. Especially some locations (eyelids, nose flap, lips, auricle) pose a challenge for the surgeon to remove the tumor entirely with proper margins and at the same time retain functionality and satisfactory aesthetic appearance. Furthermore, large, neglected tumor, especially located in the face region, demands complex reconstructive procedures after excision, i.e. local reconstruction techniques, free grafts, advanced, island, pedicle or microvascular flaps.

A male patient, aged 66, was admitted to the Department of Otolaryngology of the $5^{\text {th }}$ Military Hospital in Krakow due to large, progressive neoplastic ulceration of the right side of his face. He reported 9-year history of a slowly but gradually growing ulcerating lesion of the right buccal region. Three months before admission, he started to suffer from stabbing pain in the lower part of his face, leaking of saliva and bites of food through the ulceration, disturbances in nutrition, and unintentional,

Address for correspondence: Katarzyna Malec MD, Department of Otolaryngology, $5^{\text {th }}$ Military Hospital with Polyclinic, 1-3 Wrocławska St, 30-901 Krakow, Poland, phone: +48 608589 386, e-mail: malec.katarzyna@gmail.com

Received: 24.06.2014, accepted: 5.05.2015. 


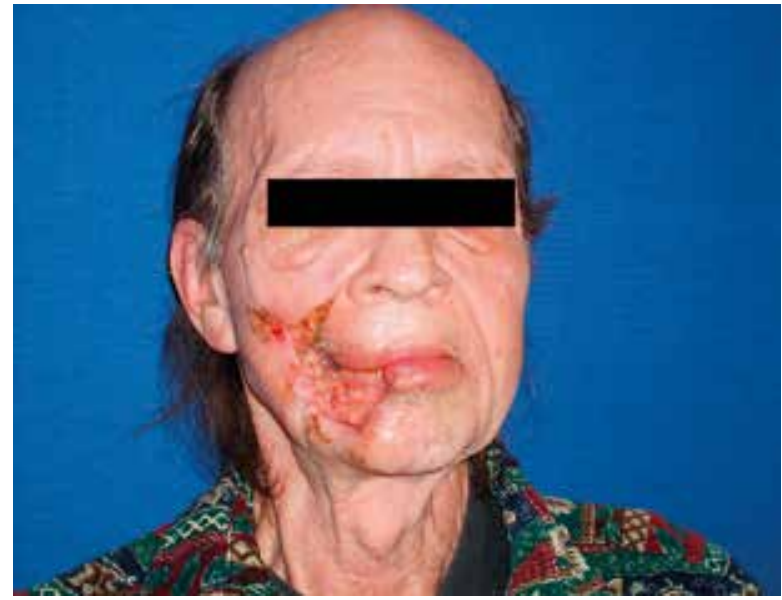

Figure 1. Large, neglected basal cell carcinoma of the right facial region

significant weight loss (approximately $15 \mathrm{~kg}$ in the past 12 months).

The patient was in good general condition (concomitant diseases were benign prostate hypertrophy, left inguinal hernia treated surgically in 1994), evaluated as Fitzpatrick's skin photo type II, abusing nicotine.

Physical examination revealed extensive, full-thickness ulceration of the right buccal region extending upward to the zygomatic arch, with destruction of the half of the upper lip and one third of the lower lip, infiltrating surrounding mimic muscles, exposing the bone of the body of the mandible, invading the mucosa of the alveolar rim of the mandible (Figures 1 and 2) [1, 2].

In the histological samples taken from the ulceration basal cell carcinoma with perineural infiltration was revealed, but the planoepithelial component could not be excluded.

The computed tomography (CT) scans revealed an extensive tissue loss and the possibility of infiltration of the mandible in the region of the right mental foramen.

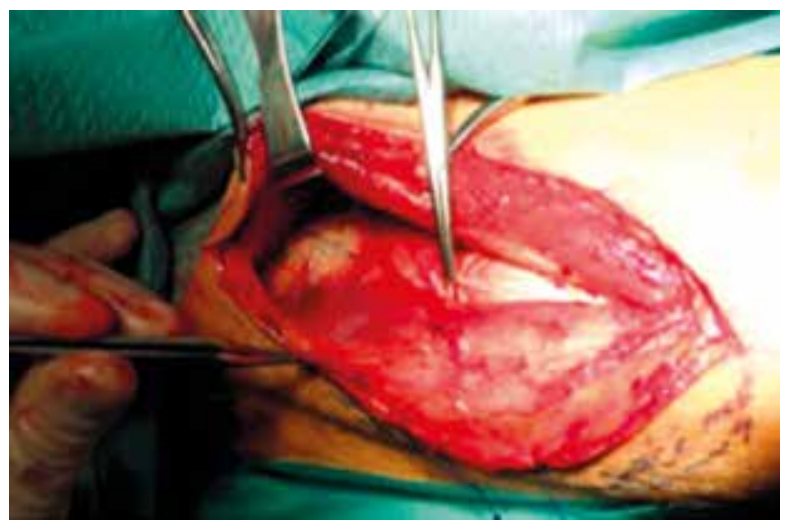

Figure 3. Harvesting of the musculocutaneous anterolateral thigh flap

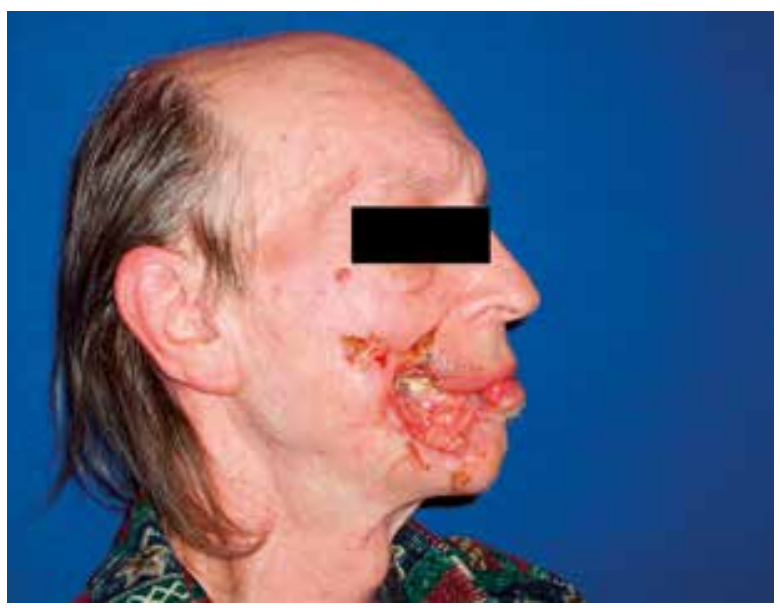

Figure 2. Large, neglected basal cell carcinoma of the facial region

The patient was qualified to the surgical treatment (Figures 3 and 4).

The first part of the procedure consisted of resection of the tumor within the histologically clean margins-right buccal region, 1/2 of the upper lip, 1/3 of the lower lip, segmental resection of the right body of the mandible, dental extraction (teeth: 41-45, 12-14) and elective right neck dissection of lymph nodes $\mathrm{I}-\mathrm{V}$ and submandibular gland (RND (I-V + SG)). The non-lymphatic structures were spared (with special concern for internal jugular vein and facial vessels). The post resection mandible loss was bridged with titanium miniplate. The abundant soft tissue defect was reconstructed with a combination of autologous split-thickness skin graft from the left thigh and microvascular musculocutaneous (based on vastus lateralis muscle) free flap antero-lateral part of the right thigh [3]. Vascular pedicle (6 cm long) consisted of one

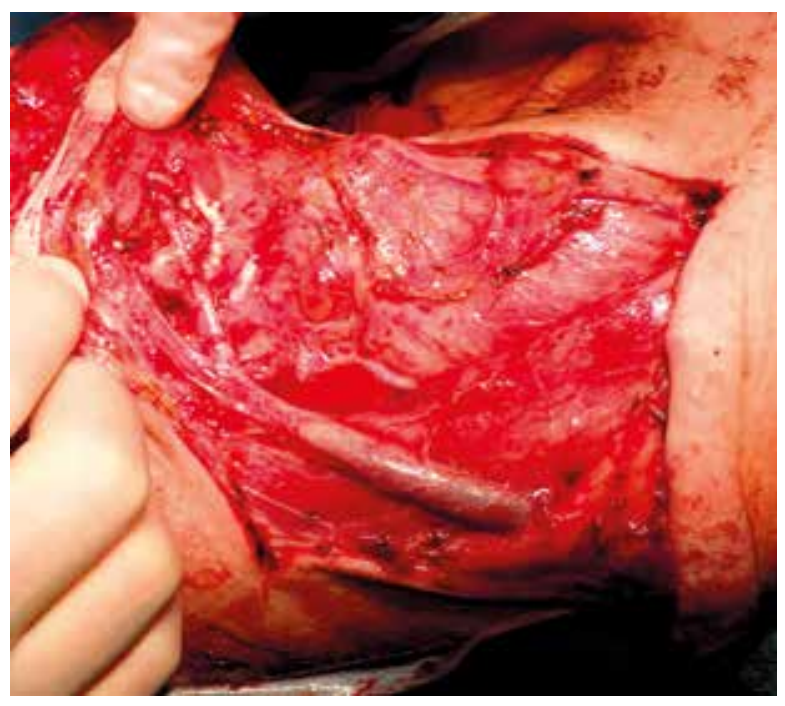

Figure 4. Microvascular anastomosis with facial vessels 
artery and two veins (diameter approximately $2 \mathrm{~cm}$ ). The microvascular end-to-end anastomosis was made to the right facial vessels [5]. Evaluation of the patency of the anastomosis was made - the blood flow was satisfactory.

In the postoperative care, the patient was monitored every $4 \mathrm{~h}$ (general condition, flap color, warmth, pin prick) administered with the analgesics, wide-spectrum antibiotics, low-molecular-weight heparin, nourished by the nasogastric tube.

In the eleventh [6] week of the post-operative period he underwent a minor procedure under local anesthesia of the reconstruction of the mouth (Figures 5 and 6) [7].

Fifteen weeks after surgery he did not complain of pain, he gained weight of approximately $8 \mathrm{~kg}$, the esthetic outcome was satisfactory.

Skin tumors are generally visible and noticeable not only for health care workers but also for the patients themselves. However typical BCCs are indolent and slowly progressive. These tumors remain painless and unobtrusive for long time. In addition, for non-specialists in skin diseases, BCC sometimes resembles noncancerous skin conditions such as psoriasis, eczema or others. The natural history of this cancer makes it an "ideal candidate" for neglected tumor.

An extremely important issue in the treatment of locally advanced tumors is the choice of the appropriate method of treatment. Numerous alternatives are available for small BCC lesions: surgical excision, Mosh micrographic surgery, photodynamic therapy, cryosurgery, immunotherapy, and radiotherapy are the most common techniques. The treatment of expansive, neglected tumors, however, often demands a multidisciplinary approach. The treatment of choice for advanced cancers is usually surgery (also neurosurgery, cranio-maxillo-facial surgery, plastic surgery) sometimes combined with radiation therapy. The key point is also the choice of the most beneficial type of reconstructive treatment after ablation of the tumor. The goal is to restore the functionality and esthetically satisfactory appearance, especially after surgery of the tumors of the head and neck with possibly small sacrifice of other tissues [13].

One of attractive reconstructive methods for large defects are free microvascular flaps. Microsurgery has evolved to focus on functional and aesthetic results, as well as donor site morbidity. The qualities of an ideal soft tissue flap for reconstructions in the head and neck region are versatility in design, adequate tissue stock, specific texture, long pedicle with an appropriate diameter of vessels, possibility of two team approach, consistent anatomy, easy and safe dissection and minimal donor site morbidity.

One of the alternatives is the anterolateral thigh flap (ALTF). It could be elevated as a cutaneous or musculocutaneous flap (based on vastus lateralis muscle) [14]. It has relatively constant anatomy, which makes dissection safe

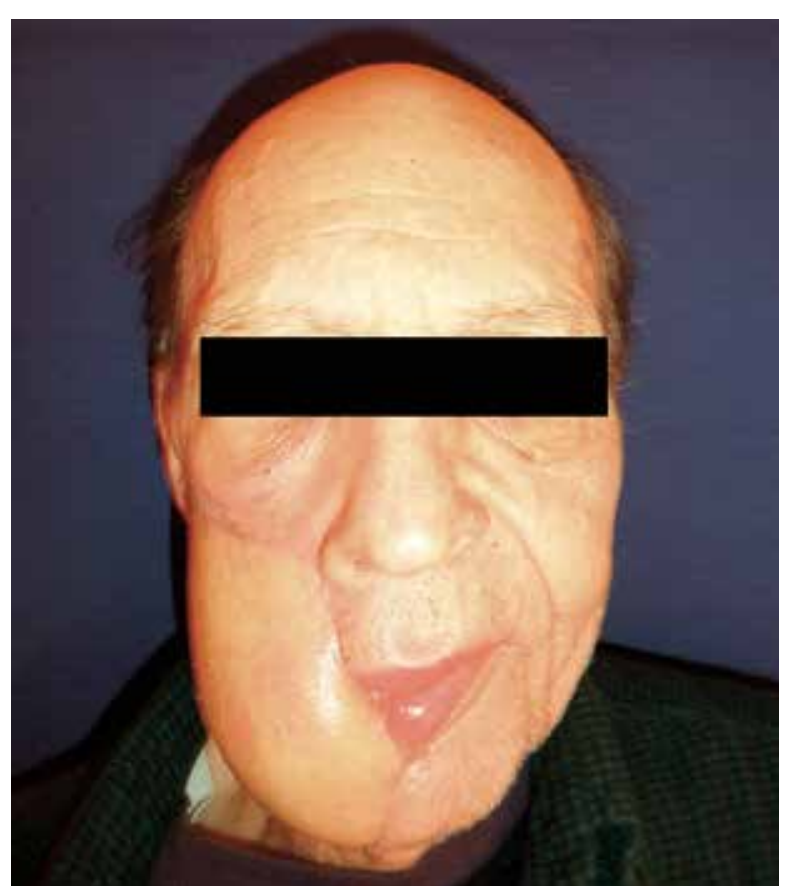

Figure 5. Eleven weeks after surgery

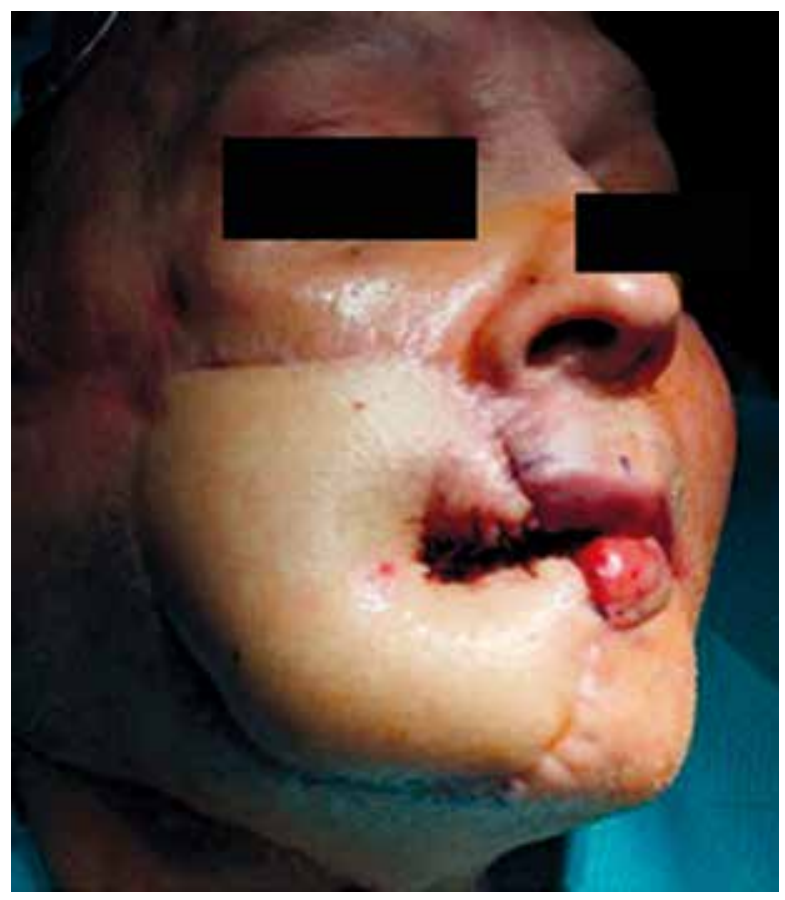

Figure 6. Reconstruction of the mouth

and easy for a skilled surgeon. Large and long pedicle, with a diameter close to potential recipient vessels of the head and neck make the microvascular anastomosis safe and easy. Harvesting ALTF is related with minimal donor site morbidity. The motor weakness is mild and transient, 
and the donor site can be closed primarily if the width of the skin island of the flap is less than $8 \mathrm{~cm}[15,16]$.

Although the anterolateral thigh flap has become the workhorse for reconstruction of the skin and soft tissue defects since Song et al. first described it in 1984, are still used very rarely.

The basal skin carcinoma, although considered to be the tumor with the low malignancy potential and not significant clinical problem, neglected advanced tumors can be encountered even in the $21^{\text {th }}$ century. There is an entire range of possibilities for the treatment of basal cell lesions, but the therapy of such neglected cases usually demands multidisciplinary surgical and oncological treatment with advanced reconstructive techniques.

\section{Conflict of interest}

The authors declare no conflict of interest.

\section{References}

1. Chinem VP, Miot HA. Epidemiology of basal cell carcinoma. An Bras Dermatol 2011; 86: 292-305.

2. Didkowska J, Wojciechowski K, Tarkowski W, et al. Nowotwory złośliwe w Polsce w 2000 roku. Instytut M. SkłodowskiejCurie. Zakład Epidemiologii Nowotworów. Krajowy Rejestr Nowotworów. Warsaw 2003.

3. Kyrgidis A, Tzellos TG, Vahtsevanos K, et al. New concepts for basal cell carcinoma. Demographic, clinical, histological risk factors, and biomarkers. A systematic review of evidence regarding risk for tumor development, susceptibility for second primary and recurrence. J Surg Res 2010; 159: 545-56.

4. Lovatt TJ, Lear JT, Bastrilles J, et al. Associations between ultraviolet radiation, basal cell carcinoma site and histology, host characteristics, and rate of development of further tumors. J Am Acad Dermatol 2005; 52: 468-73.

5. Szewczyk MP, Pazdrowski J, Dańczak-Pazdrowska A, et al. Analysis of selected recurrence risk factors after treatment of head and neck basal cell carcinoma. Postep Derm Alergol 2014; 31: 146-51.

6. Brzewski P, Wojas-Pelc A. Badanie ekspresji elongaz i desaturaz oraz składu kwasów tłuszczowych frakcji lipidowych w ogniskach raka podstawnokomórkowego skóry. Doctoral dissertation. Uniwersytet Jagielloński. Collegium Medicum. Wydział Lekarski 2012.

7. Graham Brown R, Bourke J. Mosby's Colour Atlas and text of dermatology. Elsevier, London 2007.

8. Bath-Hextall FJ, Perkins W, Bong J, et al. Interventions for basal cell carcinoma of the skin. Cochrane Database Syst Rev 2007; 1: CD003412.

9. Sobjanek M, Michajłowski I, Malek M, et al. Skin cancer in the elderly - epidemiological, clinical and surgical treatment analysis of 254 patients. Postep Derm Alergol 2012; 29: 407-10.

10. Rowe DE, Carroll RJ, Day CL Jr. Long-term recurrence rates in previously untreated (primary) basal cell carcinoma: implications for patient follow-up. Review. I Dermatol Surg Oncol 1989; 15: 315-28.

11. Rowe DE, Carroll RJ, Day CL Jr. Mohs surgery is the treatment of choice for recurrent (previously treated) basal cell carcinoma. J Dermatol Surg Oncol 1989; 15: 424-31.
12. Lear JT, Harvey I, de Berker D, et al. Basal cell carcinoma. J R Soc Med 1998; 91: 585-8.

13. Witmanowski H, Lewandowicz E, Sobieszek D, et al. Facial skin cancers: general information and an overview of treatment methods. Postep Derm Alergol 2012; 29: 240-55.

14. Wong CH, Wel FC. Anterolateral thigh flap. Head Neck 2010; 32: 529-40.

15. Chen HC, Tang YB. Anterolateral thigh flap: an ideal soft tissue flap. Clin Plastic Surg 2003; 30: 383-401.

16. Demirkan F, Chen HC, Wei FC. The versatile anterolateral thigh flap: a musculocutaneous flap in disguise in head and neck reconstruction. Brit J Plast Surg 2000; 53: 30-6. 